\title{
Development of Novel Respiratory Face Masks Prepared from Banana Stem Fiber Against Bio-Aerosols: An Eco- Friendly Approach
}

\author{
Bibaswan Sen ${ }^{1}$, Sayantani Paul ${ }^{1}$, Kanchan Kumar Bhowmik ${ }^{2}$, Surya Narayan Pradhan ${ }^{3}$, \\ Sk Imran Ali ${ }^{1, *(1)}$

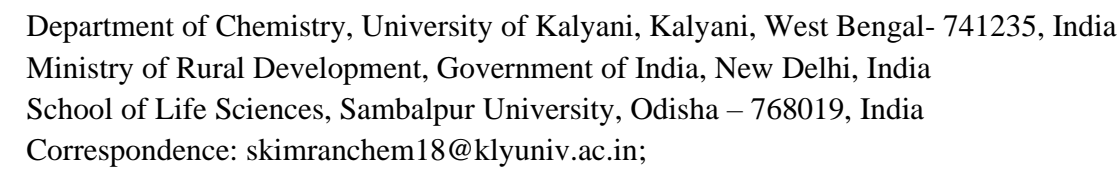

Received: 4.09.2020; Revised: 1.10.2020; Accepted: 3.10.2020; Published: 6.10.2020

\begin{abstract}
Invisible enemy, the horror of Coronavirus, has terrified the whole world for the last few months. The panacea of absolute salvation is undoubtedly vaccine, which is still under research. Scientists have emphasized on preventive measures against Coronavirus rather than cure. The use of masks is mandatory in public places. Mask preferentially prevents the absorption of harmful airborne particles circulating in the air for prolonged periods, thus non-inhibiting the respiratory cycle. In this article, we have screened various masks and developed a novel face mask derived from bio-cellulose. The present work is deliberated on banana stem fiber extracted from banana peel by applying minimal chemical treatment in a simple laboratory protocol. The banana face mask can be recycled and biodegraded with ease. The impregnated banana face mask may act as a physical screen between the transmission of bioaerosols and the respiratory tract providing high safety, security, and economic one with respect to prevalent face masks like N95, surgical masks, and others in the market.
\end{abstract}

Keywords: banana stem-fiber; bio-mask; Coronavirus; respiratory; renewability; biodegradability; bioaerosols.

Abbreviation: $\mathrm{HCoV}$; human Coronavirus; SARS; serve acute respiratory syndrome; MERS; middle east respiratory syndrome; COVID-19; coronavirus discovery in 2019; WHO; world health organization. ICTV; international committee on taxonomy of viruses. IBV; infectious bronchitis virus. PPE; personal protective equipment.

(C) 2020 by the authors. This article is an open-access article distributed under the terms and conditions of the Creative Commons Attribution (CC BY) license (https://creativecommons.org/licenses/by/4.0/).

\section{Introduction}

\subsection{Journey with Coronavirus.}

HCoV (COVID-19) caused by coronavirus-2 or SARS-CoV-2 spread almost all over the world, was declared a global pandemic by the WHO, on March 11, 2020. In late December 2019 , it was first noted that a new kind of respiratory infection came into the picture in Wuhan, China [1]. This pandemic resembles(82\% RNA genome similarity) to earlier breakout of Severe Acute Respiratory Syndrome Coronavirus (SERA-COV) from during 2002 - 2003, causing death to nearly $10 \%$ of the total infected people and the Middle East Respiratory Syndrome Coronavirus (MERS-CoV), approximately 36\% fatality rate out of total infected $[2,3]$ in 2012. A substantial economic meltdown occurred globally. Everyday life has almost 
paralyzed under the eclipse of this $\mathrm{HCoV}$. The global financial crisis is affected the market openness. People from all sections of society are compelled to stay indoors globally for their safety and well being instead of venturing out. Thus, to address the severity of airborne infection on public health aspects, researchers stressed the significance of indigenous face masks in protecting the wearer from infection.

Furthermore, to prevent subsequent community spreading of any aerosol type diseases, toxicant exposure, use of appropriate masks, and social distancing could be the realized remedy. Various masks have differential filtration abilities hence used for different purposes [4]. Considering the dimension and severity of the $\mathrm{HCoV}$, scientists and $\mathrm{WHO}$ have prioritized surgical grade N95 for rational public use. However, these masks are very costly, limited supply, and practically uncomfortable for more extended periods of usage. Accomplishing comfortable, cost-effective personal protective wear is a challenge for the bioenterpreneurs in the competitive. Here, we have proposed a bio-face mask prepared form banana fibber, which could be redeveloped further easily.

\subsection{Etymology.}

Coronavirus's microscopic image shows that the protein layers are scattered around it and an exactly look-like halo of the sun or the moon or solar corona (Figure 1). McIntosh et al. show that the particles were medium-sized (80-150 nm), pleomorphic, membrane-coated, and covered with widely spaced club-shaped surface projections [5]. WHO, officially on $11^{\text {th }}$ February 2020, renamed the new disease as "COVID-19" in consultation with ICTV.

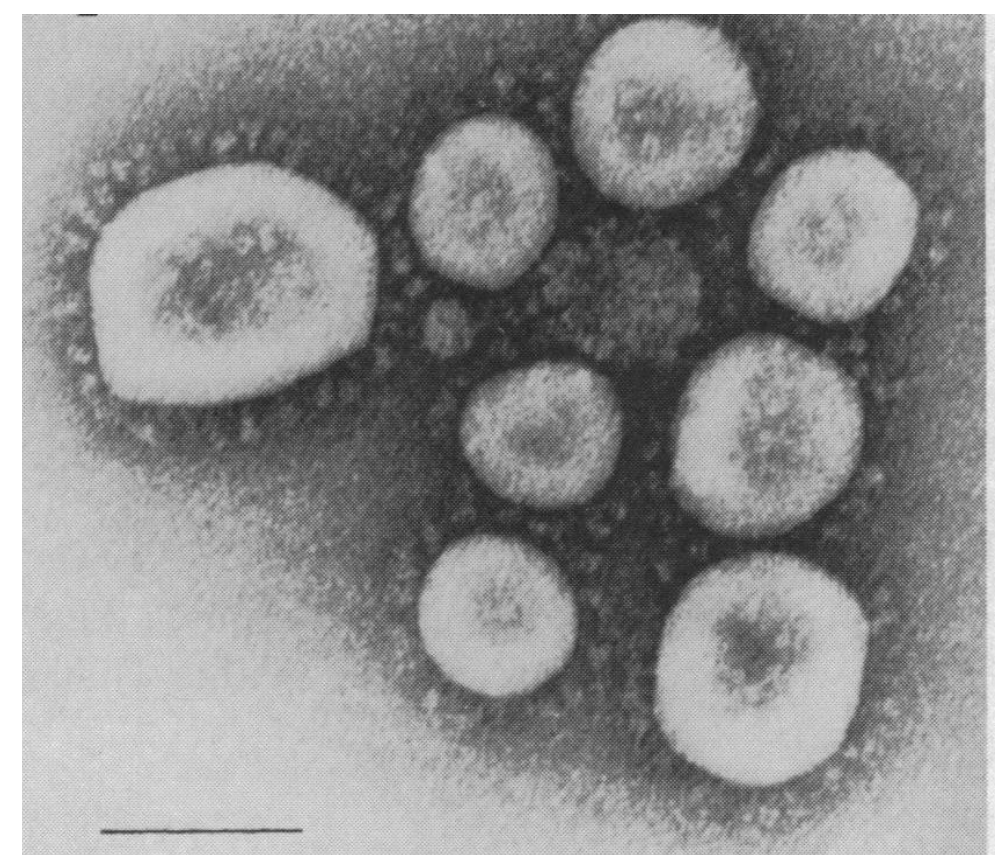

Figure 1. Microscopic image of Coronavirus [5]. Reprinted with permission from Proc Natl Acad Sci USA. 1967, 57, 933-940.

\subsection{History of $\mathrm{HCoV}$ discovery.}

By 1930, a new type of viral disease, the acute respiratory infection, was found in domestic chickens caused by the infectious bronchitis virus (IBV), a new RNA virus [6]. This new group of RNA viruses was named Coronavirus [6]. In the 1940s, two more animal coronaviruses were detected; those are transmissible gastroenteritis coronavirus (TGEV), which infects pig [7], and mouse hepatitis coronavirus (MHV) [8]. Human coronaviruses were 
first isolated in the 1960s [9]. In 1965, Tyrrel and Bynoe, working at British Medical Research Council, successfully cultivated the first $\mathrm{HCoV}$ through human embryonic tracheal and nasal organ culture, and they named this new group of viruses B814 [9]. Around the same time, Harme and Procknow at the University of Chicago have isolated a new type of virus, called 229E. The morphological similarities of B814, 229E, and IBVwere characterized under an electron microscope [9]. All three are detected or isolated in common cold conditions and tended to attack the respiratory problem. Scientists from the National Institute of Health during 1965-66 could isolate a new strain of virus stressing upon the organ culture [5]. The first global epidemic occurred with coronaviruses during 2002-2003 (SARS-CoV) and MERS-CoV in the year 2012.

\subsection{Classification of $\mathrm{HCoV}$.}

Coronaviruses constitute the family Coronaviridae, belonging to Nidovirals order [10]. Coronaviride further classified into four genera: Alphacoronaviruses (HCoV-229E [11], HCoV-NL63 [12], TGEV [13], PEDV [14], FIPV [15], CCoV [16]), Betacoronaviruses (MHA (Nedellec) [17], BCoV [18], SARS-CoV [19], MERS-CoV [20]), Gamacoronaviruses and Deltacoronaviruses.

\subsection{Structure of coronaviruses.}

Cyro-electron predicts that corona virion is spherical, and the diameter is approximately $125 \mathrm{~nm}$ [21]. Coronaviruses are adapted by the largest member of the single-strand positivesense RNA virus. They have an unusually large genome among all RNA genomes, ranging between 27 to 32 kilobase $(\mathrm{kb})$. The genome typically contains a 5'cap with 3'poly tail-the 5 'end allows RNA for the replication and transcription. The 3 'end plays a crucial role in replicating RNA and synthesis of viral RNA [22-23]. It consists of mainly four structural proteins: the nucleocapsid proteins $(\mathrm{N})$, the membrane proteins $(\mathrm{M})$, the enveloped proteins (E), and the spike proteins (S) [23]. The N-terminal protein residues in the nucleocapsid having two terminal ends: N-terminal domain (NTD) and C-terminal domain (CTD). Both domains can bind RNA protein and eventually contribute to optimal RNA binding using a different mechanism. The affinity towards the viral character of RNA is enhanced due to structural changes upon phosphorylation [24]. Binding of N protein is facilitated with the viral RNA [25, 26]. The M-protein molecular weight is $\sim 25-30 \mathrm{kDa}$ in coronavirus virion. It has a tiny $\mathrm{N}$ terminal glycosylated ectodomain and a big $\mathrm{C}$ terminal endodomain, reaching 6-8 $\mathrm{nm}$ into viral particle [27, 28]. Preprint studies suggest that $M$ protein may acquire two different conformation types, which facilitate binding nucleocapsid after promoting the membrane curvature and $M$ protein subsist as a dimer in the virion [29]. The highly divergent E-protein is found in small quantities within the coronavirus virion $(\sim 8-12 \mathrm{kDa})$. It constitutes of $\mathrm{N}$ terminal ectodomain and a $\mathrm{C}$ terminal endodomain topologically and shows activity through the ion channel. It regulates the assembly and release of the virus [30]. The spike protein is one of the important parts that mediates coronavirus entry into host cells. It consists of three segments: a large ectodomain, a single-pass transmembrane anchor, and a short intracellular tail [31]. The ectodomain contains two parts: receptor binding sub-unit S1 and membrane fusion sub-unit S2 [32]. S1 helps the virus to hold on the surface of the receptor. S2 quickly fuses the host and allowing viral genomes to penetrate host cells [32]. The spike protein formed two structurally distinct conformations, pre-fusion, and post-fusion; the transition from pre-fusion to post- 
fusion leads to membrane fusion by triggering the protein; hence host cells is affected by viruses [33-34].

\subsection{Mode of replication.}

The Spike protein of Coronavirus (SARS-CoV-2) acted as a molecular machine and forced Coronavirus entering the host cell. Coronavirus enters into the respiratory tract of humans. After binding, $\mathrm{HCoV}$ hijacks cellular machinery to make more and copies of itself. Hence, it can spread the surroundings cells [34].

\subsection{Mode of transmission.}

Presently, the rapid growth of the number of infected patients with time suggests that the virus must be transmitted through the air. Roy Anderson and Robert introduced the concept reproductive number $\left(\mathrm{R}_{0}\right)$ in their book1992. If $\mathrm{R}_{0}=1$ means one infective person infects exactly one new person. If $\mathrm{R}_{0}=2$ means one infective person infects two new persons, and so on (Figure 2) [35]. An average human can inhale particles up to $100 \mu \mathrm{m}$ in dimension, and the aerosol is relatively smaller than this. Usually, the virus spread when people cough, sneeze, and tiny droplets containing the virus are released. These droplets can undergo other person's nose, eyes, and finally enters into the host cell. A new person finally gets affected [36]. Preprint data showed that SRAS-CoV-2 remained viable in aerosol for up to 3 hours and was stable in the plastic surface up to 72 hours and 48 hours on stainless steel surface [37]. Mostly environmental sampling is undertaken in diverse establishments like malls, hospitals, govt. offices and departmental stores. To date, except for supportive treatment, no permanent solutions are available. Therefore, proper protection and awareness is the only way to survive.

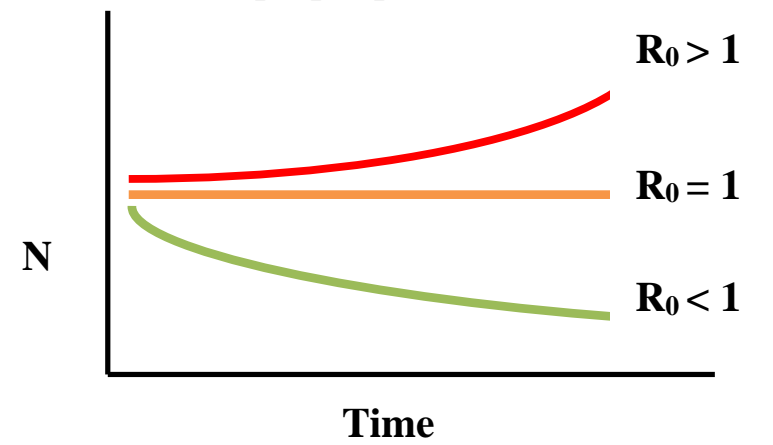

Figure 2. A plot Number of person (N) and Time. $\mathrm{R}_{0}>1$, Rapid growth of case; $\mathrm{R}_{0}=1$, no. of an infected person remain constant; $\mathrm{R}_{0}<1$, will lead to outbreak ending.

\subsection{Masks as a PPE.}

In the current situation, although we have focused on the corona, it has no hesitation in saying that the mask is not just to protect the corona but to further protect from other air pollutants. As the population grows, factories are growing to meet their needs, and the number of vehicles is increasing. The aerosols, solid, liquid, and gaseous particle suspended in air, originated from factories, cars, and fossil fuel burning. An ambient air pollutant is high and demands a high risk for people, especially among children and patients with heart diseases, cardiovascular diseases. People have trouble breathing problems to dust, yard work. For these global issues like dust allergies or asthma-related health problems, face mask choice is best [38-40]. Over the past few decades, scientists have relied on face masks to protect from disease. During the world war period, the influenza epidemic between 1918-1920, wearing a face mask 
was mandatory for health workers and police and people attached to epidemic care issues [41]. The history of masks uses very old. The travelogue of the Italian traveler Marco Polo wrote the use of masks in China in $13^{\text {th }}$ century (https:// www.globaltimes.cn.). "Brownian motion" named after Scottish researcher Robert Brown, in 1827, invented that the protective efficacy of masks on dust (https:// www.globaltimes.cn.). To walk the path alongwith with the epidemic, it is essential to wear a face mask as a PPE. The main objective behind face masks is to block them from spreading in air through droplets. Being an asymptomatic syndrome, it is impossible to understand whether he or she is affected or not. Hence, it is necessary to wear face masks for every people for their safety and community safety.

\subsection{Parameter selection.}

It is important to select parameters for designing and synthesizing a mask. The mode of action and stability of aerosol is different, and it varies with the size. The most important parameter is that the filtration ability should be the same or smaller size than aerosolized droplets $[42,43]$.

\subsection{Types of masks.}

Cloth masks are very common, cheap, and easy to make in the home. Generally, people sitting in a rural area or those who have a shortage of proper masks choose cloth masks as protection. Many preprint studies suggest that cloth masks with two to three-layer are better than a single layer. Further, It is not better but helps protect from movable larger particles in the air [43]. Masks with activated carbon coating are capable of filtrate $\mathrm{NO}_{\mathrm{x}}, \mathrm{SO}_{\mathrm{x}}, \mathrm{CO}_{\mathrm{x}}$ like toxic gases from the air [44]. Copper coating masks are generally used to protect from influenza by using the potent biocidal properties of copper [45]. At least $95 \%$ of solid or liquid aerosols can block under N95receptor capacity. Therefore, the number say 90, 95, 96 refers to the minimal percentage of aerosols filtered under test condition $^{\mathrm{s}}$ [46]. Even the above-mentioned respirator can make it more difficult for the wearer to breathe due to the building up of carbon dioxide, which may reduce oxygen intake, as consequences increased breathing rates and heart rates. Exposure to the fire zone can outweigh the benefits of the mask.

\subsection{Filtering efficiency of facemasks.}

$$
\mathrm{FE}=\frac{X_{u-X_{d}}}{X_{u}} \times 100
$$

FE, filtering efficiency of face mask. $X_{u}$, upstream air, $X_{d}$, downstream air [47].

\section{Materials and Methods}

The banana stem was stripped manually and then shaken under the mixer mechanically. It was then subjected to treat under $1 \% \mathrm{NaOH}$ solution and washed thoroughly with $1 \%$ $\mathrm{CH}_{3} \mathrm{COOH}$ solution. It was then washed thoroughly with water and dried afterward. The dry mass was added to a little surfactant or starch solution and shacked several times. The fine nano bed is developed, and it was placed in $100^{\circ} \mathrm{C}-120^{\circ} \mathrm{C}$ for 4 hours or under sunlight for $1-2$ days. Similar techniques are employed to synthesize cellulose nanofibers from banana peel from chemical treatment [50]. Nano range of $90 \mathrm{~nm}-150 \mathrm{~nm}$ is attained in the nanofibers [Figure 3]. The stepwise procedure has been shown in figure $4(\mathrm{~A}-\mathrm{F})$. It is noteworthy that nanofiber has been separated from banana peel by pretreatment, chemical treatment, mechanical 
treatment, and disintegration methods like sonication, cryo-crushing, and dissolution previously [48 - 55].

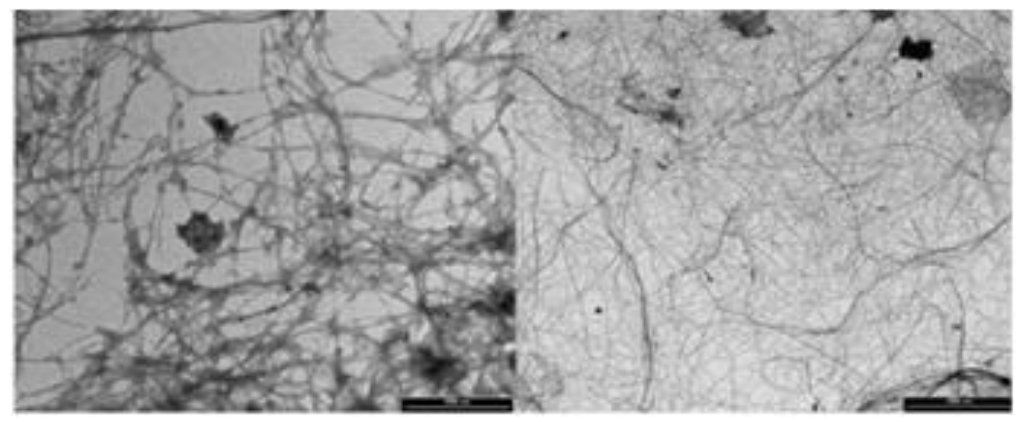

Figure 3. TEM images of the acylated cellulose nanofibers [51]. Reprinted with permission from IOSR-JAC 2017, 10, 15-19.
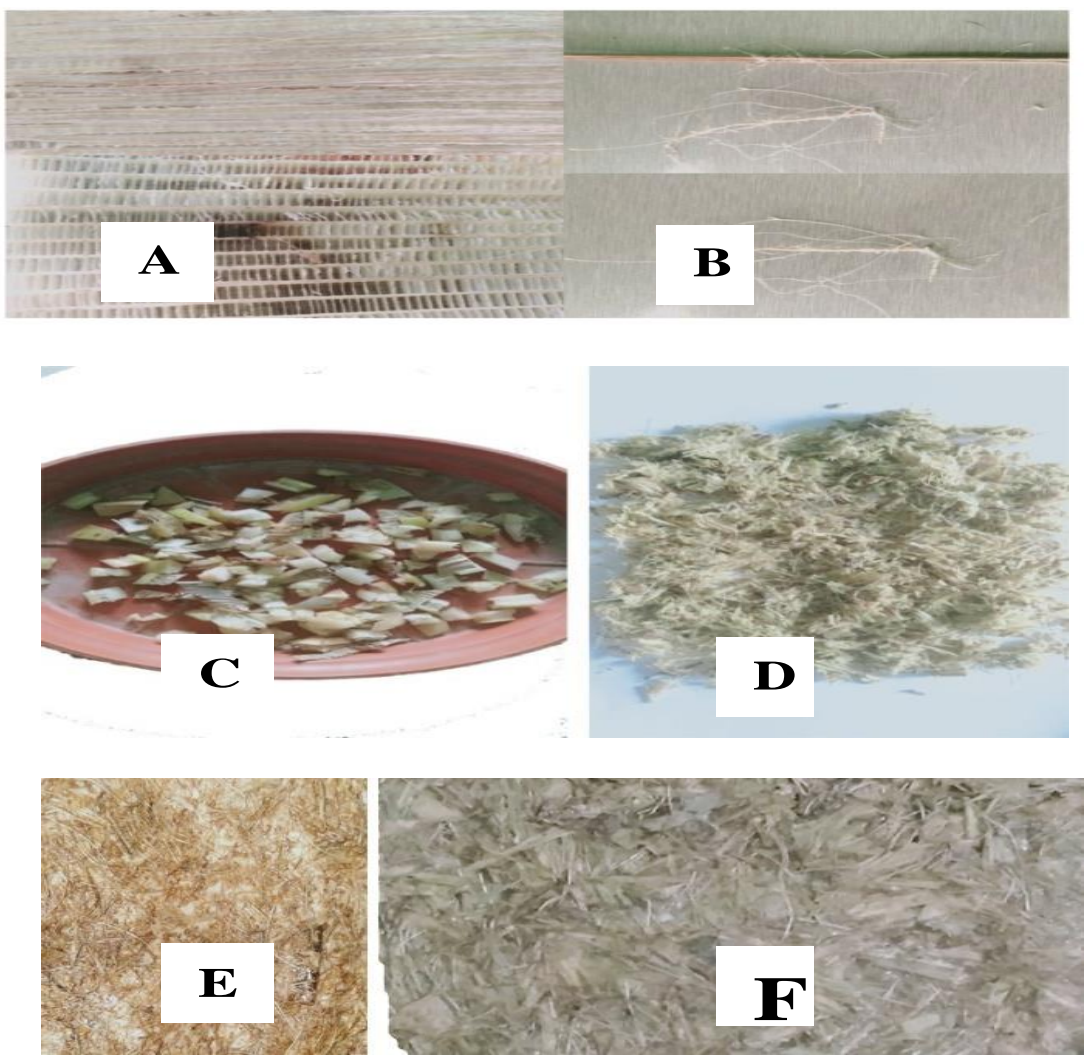

Figure 4. (A) Separation of banana bark from a Banana tree; (B) Separation of Banana Stem from banana bark or banana tree; (C) Banana peel cutting; (D) Banana stem dust; (E) Banana mask sheet wait; (F) Banana mask sheet dry.

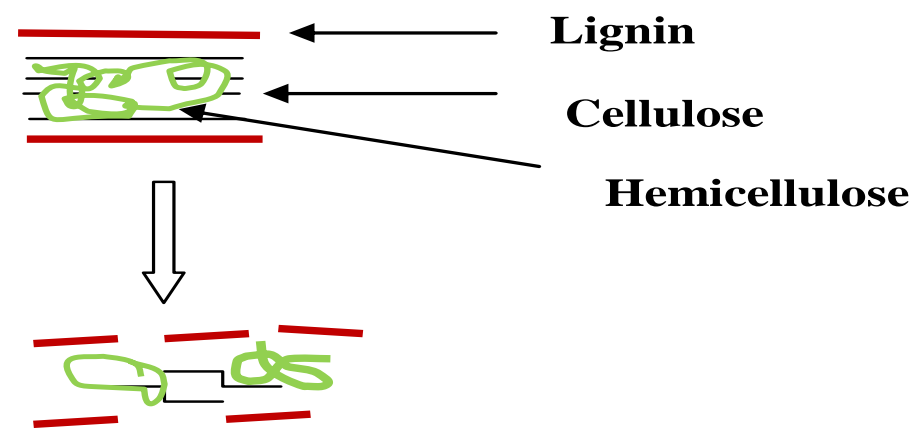

Figure 5. Degradation of the stem through alkaline hydrolysis.

The main chemical compositions of banana fiber are cellulose (60\%-62\%), hemicellulose (19\%), lignin (5-7\%), and others [56]. Cellulose is a naturally occurring fiber 
consisting of a D-anhydroglucopyranose unit linked together with $\beta$ - (1-4) glycosidic bond. They are joined with each other by hemicelluloses. The whole structure is covered through lignin [56]. Alcoholic degradation with stream explosion breaks the hemicellulose bond, disrupting lignin structure and the linkage between others cellulose or carbohydrate and making solid bio-mass into smaller ones and for a further subsequent process (see Fig. 5).

\section{Results and Discussion}

The mask was first tied to the vacuum cleaner's end, and maximum dust particles accumulated on the mask surface. The same experiment was repeated several times and showed similar results. Furthermore, the experiment was carried out with $\mathrm{NaCl}$; it was found that maximum $\mathrm{NaCl}$ was adsorbed on the mask's surface. Few particles were found in the reservoir of the vacuum cleaner. The presence of maximum dust or $\mathrm{NaCl}$ on the mask's surface indicates the quality of the filtering efficiency of the mask. The newly invented bio mask has primarily experimented as field trial among the people in the remote area of West Bengal, India, and no adverse effect regarding respiration was found with the face mask use. A schematic diagram of the mask is shown in figure $6 \mathrm{~A}-6 \mathrm{~B}$, and Figure $6 \mathrm{C}$ depicts the final face mask prepared from banana.
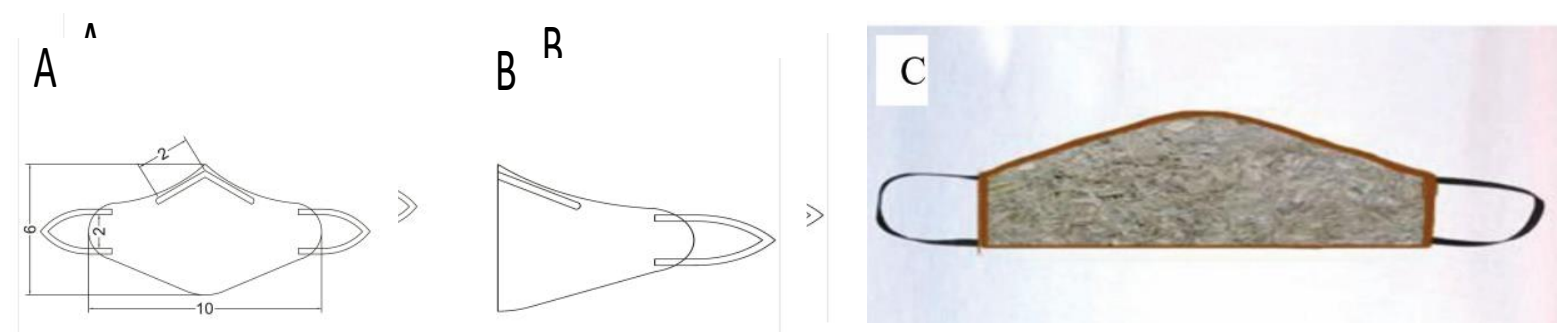

Figure 6. A. Front view of face mask. B. Side view of face mask C. 2 D view of the face mask from banana peel.

\section{Conclusions}

The evolution of the industrial benefits of banana peel as a renewable source to prepare a face mask would greatly impact our society. The newly developed bio mask would be competitive in the mask market, having better efficiency. It can help healthcare workers and common people, protecting them from viral infection and transmission. The development is very consistent with the most fundamental appeal that has grown in recent time to sustain a safe environment and a clean environment. The recent worldwide epidemic has shown the crisis of money, environmental protection, won protection. The central crisis is financial stability; the problem can be solved through sustainable implications among rural people and a renewable source of raw material. This waste plant material usability would boost employment generation, adding value to an agriculture waste and environmental benefits.

\section{Funding}

This research received no external funding.

\section{Acknowledgments}

B. S. thanks his parents for their constant support and encouragement. Special thanks to Prof. Malubendu Jana for the thoughtful discussion. Thanks to Mr. Bipradas Ghosh for designing https://nanobioletters.com/ 
the mask layout. S. I. A express his sincere appreciation to Dr. Supriya Mallik and Al-Fatehar Education Society for the distribution of the face mask to the needy people of a remote place in West Bengal, India.

\section{Conflicts of Interest}

The authors declare no conflict of interest.

\section{References}

1. Wu, F.; Zhao, S.; Mei Chen, Y.; Gana Song, Z. A new coronavirus associated with human respiratory disease in China. Nature 2020, 579, 270-273, https://doi.org/10.1038/s41586-020-2008-3.

2. Rota, P.A.; Oberste S.M.; Monroe, S.S.; Nix, A.W.; Campagnoli, R.; Icenogle, P.J.; Penaranda, S.; Bankamp, B.; Maher, K.; Chen, HM.; Tong, S.; Tamin, A.; Lowe, L.; Frace, M.; Derisi, L.J.; Chen, I.Q..; Wang, D.; Erdmam, D.D.; Peret, T.C.T.; Burns, C.; Ksiazek, G.T.; Rollin, E.P.; Sanchez, A.; Liffick, S.; Holloway, B.; Limor, J.; McCaustland, K.; Rasmussen, O.M.; Fouchier, R.; Gunther, S.; Osterhaus EMD A.; Drosten, C.; Pallansch, A.M.; Anderson, J.L.; Bellini, J. W. Characterization of a novel coronavirus associated with severe acute respiratory syndrome. Science 2003, 300, 1394-99, https://doi.org/10.1126/science.1085952.

3. de Groot, J.; Baker, R.C.; Ziebuhr, J.; Brown, S.C.; Drosten, C.; Enjuanes, L.; Fouchier, M.A.R.; Galiano, M.; Gorbalenya, E.A.; Memish, A.Z.; Perlman, S.; Poon, M.L.L.; Snijder, J.E.; Stephens, M.G.; Woo, Y.C.P.; Zaki, M.A.; Zambon, M.; Ziebuhr, J. Middle East respiratory syndrome coronavirus MERS-CoV: Announcement of the Coronavirus Study Group. J. Virol. 2013, 87, 7790-7792, https://doi.org/10.1128/JVI.01244-13.

4. Loeb, M.; Dafoe, N.; Mahony, J.; Surgical mask vs N95 respirator for preventing influenza among healthcare workers: A randomized trial. The Journal of the American Medical Association 2009, 302, 1865-1871, https://doi.org/10.1001/jama.2009.1466.

5. Maclntosh, K.; Dees H.J.; Becker W.B.; Kapikian, Z.A.; Chanock, M.R. Recovery in tracheal organ cultures of novel viruses from patients with respiratory disease. Proceedings of the national Academy of Science of the United State of America 1967, 57, 933-940, http://doi.org/10.1073/pnas.57.4.933.

6. Estola, T. Coronaviruses a new group of Animal RNA Viruses. Avian Diseases 1970, 14, 330-336, https://doi.org/10.2307/1588476.

7. Fehr, R.A.; Perlmans, S. Coronaviruses: An overview of their replication and pathogenesis, Methods in Molecular Biology. Springer 2015, 1282, 1-23, https://doi.org/10.1007/978-1-4939-2438-7_1.

8. Woo, Y.C.P.; Huang, Y.; Susanna, K.P.; Yuen, Y.K. Coronavirus Genomics and Bioinformatics Analysis. Viruses 2010, 2, 1804-1820, https://doi.org/10.3390/v2081803.

9. Khan, J.S.; McIntosh, K. History and recent advances in cronavirus discovery. The Pediatric Infectious Disease Journal 2005, 24, S223-S227, https://doi.org/10.1097/01.inf.0000188166.17324.60.

10. Enjuanes, L.; Almazan, F.; Sola, I.; Zuniga, S. Biochemical aspects of coronavirus replication and virus-host interaction. Annu. Rev. Microbial 2006, 60, 211-230, https://doi.org/10.1146/annurev.micro.60.080805.142157.

11. Yeager, L.C.; Ashmun, A.R.; Williams, K.R.; Cardellichio, B.C.; Shapiro, H.L.; Look, T.A.; Holmes, V.K. Human aminopeptidase $\mathrm{N}$ is a receptor for human coronavirus 229E. Nature 1992, 357, 420-422, http://doi.org/10.1038/357420a0.

12. Hofmann, H.; Pyrc, K.; Hoek, van der L.; Geier, M.; Berkhout, B.; Pohlmann, S. Human coronavirus NL63 employs the severe acute respiratory syndrome coronavirus receptor for cellular entry. Proc Natl Acad Sci USA., 2005, 102, 7988-7993. https://dx.doi.org/10.1073\%2Fpnas.0409465102.

13. Delmas B.; Gelfi, J.; L'Haridon, R.; Vogel, K.L.; Sjostrom, h.; Noren, O.; Laude, H. Aminopeptidase N is a major receptor for the entero-pathogenic coronavirus TGEV. Nature 1992, 357, 417-420, https://doi.org/10.1038/357417a0.

14. Li, X.B.; Ge, W.J.; Li, J.Y. Porcine aminopeptidase $\mathrm{N}$ is a functional receptor for the PEDV coronavirus. Virology 2007, 365, 166-172, https://doi.org/10.1016/j.virol.2007.03.031.

15. Tresnan, B.D.; Levis, R.; Holmes, V.K. Feline aminopeptidase $\mathrm{N}$ serves as a receptor for feline, canine, porcine, and human coronaviruses in sero group I. J. Virol. 1996, 70, 8669-8674.

16. Benbacer, L.; Kut, E.; Besnardeau, L.; Laude, H.; Delmas, B. Interspecies aminopeptidase-N chimeras reveal species-specific receptor recognition by canine Coronavirus. feline infectious peritonitis virus, and transmissible gastroenteritis virus. J. Virol. 1997, 71, 734-737.

17. Nedellec, P.; Dveksler, G. S.; Daniels, E.; Turbide, C.; Chow, B.; Basile, A. A.; Holmes, V.K.; Beauchemin, N. Bgp2, a new member of the carcinoembryonic antigen-related gene family, encodes an alternative receptor for mouse hepatitis viruses. J. Virol. 1994, 68, 4525-4537.

18. Schultze, B., Herrle, R. G. Bovine coronavirus uses N-acetyl-9-O-acetylneuraminic acid as a receptor determinant to initiate the infection of cultured cells. J. Gen. Virol. 1992, 73, 901-906, https://doi.org/10.1099/0022-1317-73-4-901.

https://nanobioletters.com/ 
19. Li, W.; Moore, M.J.; Farzan, M. Angiotensin-converting enzyme 2 is a functional receptor for the SARS coronavirus. Nature 2003, 426, 450-454, https://doi.org/10.1038/nature02145.

20. Raj, S.V.; Mou, H.; Smits, L.S.; Dekkers, Dick, W.H.; Muller, A.M.; Dijkman, R.; Muth, D.; Demmers A.A.J.; Zaki, A.; Fouchier, M.A.R.; Theil, V.; Drosten, C.; Rottier, M.J.P.; Osterhaus, E.M.D.A.; Bosch, J.B.; Haagmans, L.B. Dipeptidyl peptidase 4 is a functional receptor for the emerging human coronavirusEMC. Nature. 2013, 495, 251-254, https://doi.org/10.1038/nature12005.

21. Barcena, M.; Oostergetel, T.G.; Bartelink, W.; Faas, A.G.F.; Verkleij, A.; Rottier, M.J.P.; Koster, J.A.; Bosch, J.B. Cyro-electron tomography of mouse hepatitis virus: Insights into the structure of the coronavirion. Proc Natl Acad. Sci., U S A. 2009, 106, 582-587, https://doi.org/10.1073/pnas.0805270106.

22. Zhao, L.; Jha, B.K.; Wu, A.; Elliott, R.; Ziebuhr, J.; Gorbalenya, E.A.; Silverman, H.R.; Weiss, R.S. Antagonism of the interferon-induced OAS- RNase L pathway by murine Coronavirus ns 2 protein is required for virus replication and liver pathology. Cell Host Microb. 2012, 11, 607-616, https://doi.org/10.1016/j.chom.2012.04.011.

23. Anthony, R.F.; Stanley, P. Coronaviruses: An overview of their replication and pathogenesis. Nature 2015, 1282, 1-23, https://doi.org/10.1007/978-1-4939-2438-7_1.

24. Stohlman, S.A.; Lai, M.M. Phosphoproteins of murine hepatitis viruses. J. Virol. 32, 672-675.

25. Chang, C.K.; Sue, C.S.; Yu, H.T.; Yu, H.T.; Hsieh, M.C.; Tsai, K.C.; Chiangg, C.Y.; Lee, J.S.; Hsiao, H.H.; Wu, J.W.; Chang, L.W.; Lin, H.C.; Huang, H.T. Modular organization of SARS coronavirus nucleocapsid protein. J. Biomed. Sci. 2006, 13, 59-72, https://doi.org/10.1007/s11373-005-9035-9.

26. Hurst, K.R.; Koetzner, C.A.; Masters, P.S. Identification of in vivo-interacting domains of the murine coronavirus nucleocapsid protein. J. Virol. 2009, 83, 7221-7234, https://doi.org/10.1128/JVI.00440-09.

27. Armstrong, J.; Niemann, H.; Smeekens, S.; Rottier, P.; Warren, G.; Sequence and topology of a model intracellular membrane protein, E1 glycoprotein, from a coronavirus. Nature 1984, 308, 751-752, https://doi.org/10.1038/308751a0.

28. Nal, B.; Chan, C.; Kien, F.; Siu, L.; chu, K.; Kam, J.; Staropli I.; Crescenzo-chaigne, B.; Escriou, N.; van der W. S.; Yuen, R.; Altmeyer, K. Y.; Differential maturation and subcellular localization of severe acute respiratory syndrome coronavirus surface proteins S, M and E, J. Gen. Virol. 2005, 86, 1423-1434, https://10.1099/vir.0.8067-0.

29. Neuman, W.B.; Kiss, G.; Kunding, H.A.; Bhela, D.; Baksh, F.M.; Connelly, S.; Droese, B.; Klaus, P.J.; Makino, S.; Sawicki, G.S.; Siddell, G.S.; Stamou, G.D.; Wilson, A.L.; Kuhn, P.; Buchmeier, J.M. A structural analysis of M protein in coronavirus assembly and morphology. J. Struct. Biol. 2011, 174, 11-22, https://doi.org/10.1016/j.jsb.2010.11.021.

30. Godet, M.; L'Haridon, R.; Vautherot, J.F.; Laude, H. TGEV corona virus ORF4 encodes a membrane protein that is incorporated into virions. Virology 1992, 188, 666-675, https://doi.org/10.1016/00426822(92)90521-P.

31. Walls, C.A.; Tortorici, A.M.; Bosch, J.B.; Frenz, B.; Rottier, J.P.; DiMaio, F.; Rey, A.F.; Veesler, D. Cryoelectron microscopy structure of a coronavirus spike glycoprotein trimer. Nature 2016, 531, 114-17, https://doi.org/10.1038/nature16988.

32. Li, F.; Berardi; M.; Li, W.H.; Farzan, M.; Dormitzer, P.R.; Harrison; S.C. Conformational states of the severe acute respiratory syndrome coronavirus spike protein ectodomain. J. Virol. 2006, 80, 6794-800, https://doi.org/10.1128/jvi.02744-05.

33. Kirchdoerfer, N.R.; Cottrell, A.C.; Wang, N.; Pallesen, J.; Yassine, M.H.; Turner, L.H.; Corbett, S.K.; Graham, S.B.; McLellan, S.J.; Ward, B.A. Pre-fusion structure of a human coronavirus spike protein. Nature. 2016, 531, 118-21, https://doi.org/10.1038/nature17200.

34. Fang, L. Structure, function, and evolution of coronavirus spike proteins. The Annual Review of Virology 2016, 3, 237-61, https://doi.org/10.1146/annurev-virology-110615-042301.

35. Howard, J.; Huang, A.; Li, Z.; Tufekci, Z.; Zdimal, V.; van der Westhuizen, H.; von Delft, A.; Price, A.; Fridman, L.; Tang, H.L.; Tang, V.; Waston, L.G.; Bax, E.C.; Shaikh, R.; Questier, F.; Hernandez, D.; Chu, F.L.; Ramirez, M.C.; Rimoin, W.A. Face masks against COVID-19: An evidence review. Preprints 2020, https://doi.org/10.20944/preprints202004.0203.v1.

36. Liu, J.; Liao, X.; Qian, S.; Yuan, J.; Wang, F.; Liu, Y.; Wang, Z.; Wang, S.F.; Liu, L.; Zhang, Z. Community transmission of Severe Acute Respiratory Syndrome Coronavirus 2, Shenzhen, China, Emerging Infectious Diseases. EID Journal 2020, 26, 1320-1323, https://doi.org/10.3201/eid2606.200239.

37. 37. van Doremalen, N.; Bushmaker, T.; Morris, D.H. Aerosol and Surface Stability of SARS-CoV-2 as Compared with SARS-CoV-1. N. Engl. J. Med. 2020, 382, 1564-1567, https://doi.org/10.1056/NEJMc2004973.

38. Moore, D.; Copes, R.; Fisk, R.; Joy. R.; Chan, K.; Bauear, M. Population health effects of air quality changes due to forest fires in British Columbia. Estimates from physician-visit billing data. Canadian journal of public health. 2003, 97, 105-108, https://doi.org/10.1007/BF03405325.

39. Langrish, J.P.; Li, X.; Wangetal, S. Reducing personal exposure to particulate air pollution improves cardiovascular health in patients with coronary heart disease Environmental Health Perspective 2012, 120, 367-372, https://doi.org/10.1289/ehp.1103898. 
40. Guan, W.; Zheng, X.; Chung, K.F.; Zhong, N. Impact of air pollution on the burden of chronic respiratory diseases in China: time for urgent action. The Lancet 2016, 388, 1939-1951, https://doi.org/10.1016/s01406736(16)31597-5.

41. Strasser, B.J.; Schlich, T. A history of medical mask and rise throwaway culture. Perspectives 2020, 396, 19-20, https://doi.org/10.1016/S0140-6736(20)31207-1.

42. Atrie, D.; Worster, A. Surgical mask versus N95 respirator for preventing influenza among health care workers: A randomized trial. Canadian Journal of Emergency Medicine 2012, 14, 50-52, https://doi.org/10.1001/jama.2009.1466.

43. Macintyre, R.C.; Seale, H.; Dung, C.T.; Hien, T.N.; Nga, T.P.; Chughatai, A.A.; Rahman, B.; Dwyer, E.D.; Wang, Q. A cluster randomised trial of cloth masks compared with medical masks in healthcare workers, BMJ Open 2015, 5, https://doi.org/10.1136/bmjopen-2014-006577.

44. Khayan, K.; Anwar, T.; Wardoyo, S.; Puspit, W.L. Active carbon respiratory masks as the adsorbent of toxic gases in ambient air. Hindawi Journal of Toxicology 2019, 7, https://doi.org/10.1155/2019/5283971.

45. Borkow, G.; Zhou, S.S.; Page, T.; Gabbay, J. A novel anti-influenza copper oxide containing respiratory face mask, PLoS ONE 2010, 5, https://doi.org/10.1371/journal.Pone.0011295.

46. Cook, M.T. Personal protective equipment in COVID-19 pandemic - a narrative review. Anaesthesia 2020, 75, 920-927, https://doi.org/10.1111/anae.15071.

47. Davies, A.; Thompson, A.K.; Giri, K.; Kafatos, G.; Walker, J.; Bennelt, A. Testing the efficacy of homemade masks: Would they protect in an influenza pandemic, Disaster Med Public Health Preparedness. Society for Disaster Medicine and Public Health. Inc. 2013, 7, 413-418, https://doi.org/10.1017/dmp.2013.43.

48. Montanari, S.; Roumani, M.; Heux, L.; Michel, R. Topochemistry of carboxylated cellulose nanocrystals resulting from TEMPO-medicated oxidation. Vigno, Macromolecule 2005, 38, 1665-1671, https://doi.org/10.1021/ma048396c.

49. Thygesen, A.; Oddershede, J.; Lilholt, H.; Thomsen, B.; Stahl, K. On determination of crystallinity and cellulose content in plant fiber. Cellulose 2005, 12, 563-576, https://doi.org/10.1007/s10570-005-9001-8.

50. Ramesh, A.; Krishnan, N.V. Synthesis and characterization of surface modified cellulose nanofiber from Banana Peel. IOSR-JAC 2017, 10, 15-19, https://doi.org/10.9790/5736-1001021519.

51. Khawas, P.; Deka, C.S. Isolation and characterization of cellulose nanofibers banana peel using highintensity ultrasonocation combined with chemical treatment. Carbohydrate Polymer 2015, 137, 608-616, https://doi.org/10.1016/j.carbpol.2015.11.020.

52. Tibolla, H.; Pelissari, F.; Menegalli, C.F. Cellulose nanofibers produced from banana peel by chemical and enzymatic treatment. LWT-Food Science and Technology 2014, 59, 1311-1318, https://doi.org/10.1016/j.lwt.2014.04.011.

53. Nishino, T.; Matsuda, I.; Hirao, K. All cellulose composite. Macromolecule 2004, 37, 7683-7687, https://doi.org/10.1021/ma049300h.

54. Nogi, M.; Handa, K.; Nakagatio, N.A.; Yano, H. Optically transparent bionanofiber composites with low sensitivity to refractive index of the polymer matrix. Appl. Phys. Lett. 2005, 87, https://doi.org/10.1063/1.2146056.

55. Shimazaki, Y.; Miyazaki, Y.; Tekezawa, Y.; Nogi, M.; Abe, K.; Ifuku, S.; Yano, H. Excellent Thermal Conductivity of Transparent Cellulose Nanofiber /Epoxy Resin, Nanocomposites. Biomolecules 2007, 8, 2976-2978, https://doi.org/10.1021/bm7004998.

56. Deepa, B.; Abraham, E.; Cherian, M.B.; Bismarck, A.; Blaker, J.J.; Pothan, A.L.; Leao, L.A.; de Souza, F.S.; kottaisamy, M. Structure, morphology and thermal characteristics banana nano fibers obtained by stem explosion. Bioresource Technology 2011, 102, 1988-1997, https://doi.org/10.1016/j.biortech.2010.09.030. 